\title{
FENNTARTHATÓ FOLYÉKONY BIOÜZEMANYAGOK KILÁTÁSAI
}

\author{
OLÁH Judit - ERDEI Edina - POPP József
}

\section{Összefoglalás}

Az EU a fenntarthatóság globális éllovasa, és a megújuló energiáról szóló irányelv és az üzemanyag-minőségére vonatkozó irányelv értelmében meghatározzák azokat a fenntarthatósági kritériumokat, amelyeknek a bioüzemanyagoknak meg kell felelniük ahhoz, hogy beszámitható legyen a 2020-ig kötelezöen vállalt nemzeti célok teljesitésébe. A 2018 decemberében jóváhagyott és a 2020-2030 közötti időszakra szóló megújuló energiáról szóló irányelv a megújuló energiaforrások 14\%-os részesedését tüzi ki célul 2030-ra a közlekedési ágazatban, ebböl legalább 3,5\%-os részcélként a fejlett bioüzemanyagok és biometán arányát. Az irányelv emellett 7\%-os felsö határt ir elö az élelmiszernövényekböl készült hagyományos bioüzemanyagok részarányára, ami tükrözi az EU aggodalmát az élelmiszerek és az üzemanyagok termöföldért folytatott versenye és a közvetett földhasználat-változás miatt. Az Egyesült Államokban a Környezetvédelmi Ügynökség felel a megújuló üzemanyag szabványra vonatkozó programért. Ez a program specifikus éves mennyiségi követelményeket határoz meg a megújuló üzemanyagokra, amelyek 2022-re 36 milliárd gallonra emelkednek. Ezek a szabályozási követelmények az Egyesült Államokban használt megújuló üzemanyagok hazai és külföldi gyártóira és importöreire vonatkoznak.

Kulcsszavak: bioüzemanyag, bioetanol, biodizel, fenntarthatóság JEL kód: $Q 41, Q 42, Q 43$

\section{OUTLOOK OF SUSTAINABLE LIQUID BIOFUELS PRODUCTION}

\section{Summary}

The EU is the global frontrunner on sustainability and has introduced regulations under the Renewable Energy Directive and Fuel Quality Directive that lay down sustainability criteria that biofuels must meet before being eligible to contribute to the binding national targets that each Member State must achieve by 2020. In Europe, the revised EU Renewable Energy Directive for 2020-2030, approved in December 2018, sets a target for a 14\% share of renewable energy in the transport sector by 2030, with a sub-target of at least $3.5 \%$ use of advanced biofuels and biomethane. The Directive also places a 7\% cap on the share of the overall target that can be met by conventional biofuels based on feedstocks that also could be used as food, reflecting EU concerns about competition between food and fuel and about potential indirect land-use change impacts. In the United States, the Environmental Protection Agency is responsible for the Renewable Fuel Standard program. This establishes specific annual volume requirements for renewable fuels, which rise to 36 billion gallons by 2022. These regulatory requirements apply to domestic and foreign producers and importers of renewable fuel used in the U.S.

Keywords: biofuel, bioethanol, biodiesel, sustainability 


\section{Bevezetés}

A bioüzemanyaggyártás bővítése negatív környezeti hatásokhoz vezethet és megnehezítheti a nemzetközi környezetvédelmi megállapodások elöírásainak teljesítését. Például a bioüzemanyaggyártáshoz különböző alapanyagokat állítanak elő számos régióban adott talajés vízviszonyok mellett, míg a társadalmi szempontok (például a munkakörülmények vagy a megfelelö élelmiszerellátás) figyelembevétele még bonyolultabb feladat. LUZADIS et al. (2008) a legújabb tudományos ismereteket és társadalmi értékeket magában foglaló rendszert dolgoztak ki a bioenergia fenntarthatóságának becslésére. GROOM et al. (2008) 12 szakpolitikai ajánlást fogalmazott meg a bioüzemanyagokra vonatkozó tanúsítási szabványok kidolgozásának elösegítéséhez, beleértve a három általános alapelvet: a fenntartható, környezetkímélő alapanyagok előállítása kis ökológiai lábnyom mellett, az őshonos és alapvető élelmiszernövények élöhelyeinek fenntartása, valamint a karbonsemleges bioüzemanyagok termelése. A fenntartható bioüzemanyagok széles körben elfogadott definíciója, valamint a tanúsítás és a jelölés (címkézés) globális rendszere még mindig hiányzik, habár bizonyos fokú egyetértés már mutatkozik ökológiai kérdésekben, mint például az ÜHG-kibocsátás, az energiamérleg, a csökkenő biodiverzitás és speciális környezeti károk (talajállapot, vízfelhasználás stb.).

\section{Szakirodalmi áttekintés}

A bioüzemanyaggyártás globális terjedése komoly vitákat váltott ki, elsősorban a környezeti és társadalmi fenntarthatóság kérdésében, mint például az élelmiszertermelésre, a földhasználat változására, a biodiverzitásra, az energiahatékonyságra és az éghajlatváltozásra gyakorolt hatása [SEARCHINGER-HEIMLICH, 2015; CORREA et al., 2019; MEYER et al., 2021]. A bioüzemanyagok előállításához kapcsolódó gazdasági, társadalmi és környezeti problémákat számos tudományos közlemény tárgyalta [RAMCILOVIC-SUOMINEN-PÜLZL, 2018; FRÓNA et al., 2019]. A gazdasági, társadalmi és környezeti problémák összetettsége holisztikus perspektívát feltételez a potenciális szinergia hatás előnyeinek érvényesítése érdekében. A tanúsítási rendszerek alkalmazása a legjobb eszköz a fenntartható bioenergetikai rendszerek fejlesztéséhez [LADANAI-VINTERBÄCK, 2009]. A bioüzemanyagok fenntarthatósági értékeléséhez multikritérium elemzés szükséges [LORA et al., 2011]. A bioüzemanyagok fenntarthatósága tulajdonképpen a gazdasági, társadalmi és környezeti dimenziók közötti optimalizálásról szól [MANGOYANA et al., 2013; VALKÓ et al.,2017].

A bioüzemanyagok kevesebb ÜHG-t, különösen $\mathrm{CO}_{2}-\mathrm{t}$ bocsátanak ki, mint a fosszilis üzemanyagok, mivel a bioüzemanyag égése során kibocsátott $\mathrm{CO}_{2}$ mennyisége megegyezik az alapanyag növekedése során lekötött mennyiséggel. Ez csak abban az esetben igaz, ha nem képződik további $\mathrm{CO}_{2}$-kibocsátás a földhasználat-változás során. A földhasználat-változás lehet közvetlen (pl. erdőterület átalakítása mezőgazdasági területté a tárolt szén elvesztésével), vagy közvetett (pl. az élelmiszernövényeket bioüzemanyagok gyártására használják fel), ennek ellentételezésére pedig máshol (marginális terület, gyepterület stb.) kell több termőföldet megmüvelni), vagyis a bioüzemanyag-gyártáshoz felhasznált növények ÜHG-kibocsátása mellett további emisszióval jár az élelmiszernövények termesztésébe bevont új területek müvelése. A termőföldért folytatott verseny a bioüzemanyag- és élelmiszeripar között megszűnik, ha a bioüzemanyagot nem élelmezési célú biomasszából állítják elő. A bioüzemanyagok gyártásával kapcsolatban leggyakoribb kritika a földhasználat-változásra és az élelmezésbiztonságra gyakorolt negatív hatások. Emellett a bioüzemanyag-termelés a 
biodiverzitásra, a vízkészletre, a vízminőségre és a talajminőségre is hátrányos lehet. A bioüzemanyagok fosszilis üzemanyagokhoz viszonyított alacsonyabb ÜHG kibocsátása csak akkor érvényesül, ha azok elöállítása nem jár földhasználat-változással elöidézett további emisszióval.

A multifunkcionalitás kritériumai érvényesek a többfunkciós folyékony bioüzemanyagokra is, mivel a multifunkcionális bioüzemanyag elöállítása csökkentheti a földhasználat változásra nehezedő nyomást [IGNACIUK, 2006]. A fenntartható bioüzemanyagok szakirodalma hosszú ideig egyetlen kérdésre összpontosított, például az alapanyagok marginális területen történő előállítására a magas termőképességü terület helyett annak érdekében, hogy csökkenjen az élelmiszer-termeléssel folytatott verseny [CAMPBELL et al., 2008]. Ezenkívül a marginális területek jelentős inputokat (tápanyag és víz) igényelnek a termelékenység fenntartása céljából. A növekvő biomassza előállítás megköveteli az összes erőforrás optimalizálását az erőforrásigényekkel járó kockázatok minimalizálása érdekében [GOPALAKRISHNAN et al., 2009]. Az értéklánc fázisaiban érdekelt gazdasági szereplők részvétele kritikus tényezőnek számít a bioenergetikai rendszer fenntarthatósága szempontjából [BUCHHOLZ et al., 2007]. Mind a környezeti, mind a gazdasági célkitüzések megvalósíthatók a gazdasági és környezeti hatások optimalizálásával [SRIVASTAVA, 2007]. Az újabb generációs bioüzemanyagok fejlesztése enyhítheti az élelmiszer, a takarmány és a bioüzemanyagok elöállítása közötti versenyt, de az alapanyagok iparszerü termesztése hatást gyakorol a többi erőforrásra és a földhasználatra [KAZAMIA-SMITH, 2014].

A környezeti fenntarthatóság egyik kulcseleme a bioüzemanyagoknak az a képessége, hogy enyhítsék az ÜHG-kibocsátást [BRITZ-HERTEL, 2011; MAGDA-TÓTH, 2019]. A bioüzemanyagok életciklusa során kibocsátott nettó ÜHG fontos szempont. A hagyományos üzemanyagok ÜHG-kibocsátásával összehasonlítva a bioetanol (kukorica-, cukornád- és cellulózalapú) és biodízel kibocsátása 10-95\% között alakul [DE OLIVEIRA et al., 2005]. A bioüzemanyaggyártás alapanyagainak termesztése környezetbarát mezőgazdasági gyakorlatot feltételez. Az alapanyagok fenntarthatósága a helyes környezetvédelmi gyakorlat függvénye az üzemanyaggyártás teljes életciklusa során. Továbbá indokolt minimalizálni a bioüzemanyag ökológiai lábnyomát, így az alapanyagok előállításához szükséges földterület nagyságát is [GROOM et al., 2008; HARSÁNYI et al., 2021; MOHAMMED et al., 2021]. A bioüzemanyagokra jellemző környezeti fenntarthatósági mutatók hat nagy kategóriába sorolhatók, nevezetesen a talaj minősége, a víz minősége és mennyisége, a levegő minősége, az éghajlatváltozás, a biológiai sokféleség és a növények fajlagos hozama [MCBRIDE et al., 2011].

Számos tanulmány feltárta a bioüzemanyag elöállitásának a biodiverzitásra gyakorolt hatását. A bioetanol termelés környezeti hatása csökkenthető a technológia és az új ismeretek fejlesztésével. HELLMANN-VERBURG (2010) kimutatták, hogy a Megújuló Energia Irányelv (Renewable Energy Directive: RED) bioüzemanyagra vonatkozó célkitüzés közvetlen földhasználat-változásra gyakorolt hatása csekély, míg a közvetett földhasználat-változásra kifejtett hatása $8 \%$ is lehet a célkitüzés nélküli szcenárióval összehasonlítva. EGGERS et al., (2009) szerint a bioüzemanyag előállítás növekedésével több faj élőhelye tovább szükül, habár az EU-ban a növekvő bioüzemanyaggyártással járó élőhely-veszteség sokkal kisebb a demográfiai, gazdasági, politikai és technológiai fejlődés által okozott veszteségeknél. A megújuló energia, ideértve a bioüzemanyagokat is, lehetőséget teremt az éghajlatváltozás mérséklésére az ÜHG-kibocsátás csökkentésével, ráadásul csökkenti az alacsony és közepes jövedelmü országok energiaimportjának számláját [KHAN et al., 2010].

A bioenergia fenntarthatóságának gazdasági szempontjai között szerepel az alapanyagok rövid és hosszú távú jövedelmezősége, a különböző tüzelőanyagok gyártási, szállítási és disztribúciós költségei. Gazdasági szempontból a bioüzemanyagok támogatási politikájának a költséghatékonysága gyakran megkérdőjelezhető [OECD, 2009]. A gazdasági tényezőket 
befolyásolják az állami támogatások, az energia, ezen belül a bioüzemanyag elöállításhoz szükséges alapanyagok piaci ára, a diverzifikált energiafelhasználás iránt mutatkozó kereslet és a környezetre gyakorolt hatás [DALE et al., 2013]. A nemzetgazdasági összehasonlítások során kimutatásra került, hogy az EU országokon belül a biomassza alapú energiatermelés növekedése a kezdeti eufória után megtorpanni látszik, azonban szintjének fenntartása fontos gazdasági érdek [LÁSZLÓK et al., 2020]. A piacszerkezet is befolyásoló tényező, mert a támogatások ,elszivároghatnak” más piaci szereplőkhöz a termelőkön kívül. Ezen túlmenően a beruházási költségek és annak megtérülése, a bioüzemanyagok és egyéb mezőgazdasági termékek ára, valamint a foglalkoztatás szintén nagy jelentőséggel bírnak [MANGOYANA et al., 2013].

A fenntartható bioenergia társadalmi szempontjai magukban foglalják az élelmezés- és energiabiztonságot, valamint a lakosság és az érintett régiók megélhetésének biztosítását. Ide tartozik az emberi jogok tiszteletben tartása és a hosszú távú fenntarthatósági célok teljesítése rendszeres monitoring mellett [DALE et al., 2013; HARANGI-RÁKOS et al., 2017; POPP et al., 2017; HARANGI-RÁKOS et al., 2018; OLÁH et al., 2020]. A bioüzemanyagok társadalmi fenntarthatóságáról szóló szakirodalomak a szegénység elleni küzdelemre összpontosított a világ kevésbé fejlett régióiban a bioüzemanyaggyártó vállalkozások foglalkoztatásra, jövedelemtermelésre, helyi tulajdonjogra és energiaellátásra, valamint élelmiszertermelésre gyakorolt hatásait vizsgálva [MANGOYANA, 2009]. Társadalmi szempontból a gyorsan növekvő bioüzemanyag előállítás az élelmiszerárakra és az élelmezésbiztonságra gyakorolt hatása a 2007/2008-as globális pénzügyi és gazdasági válság idején különösen ellentmondásos volt. Számos tanulmány elemezte a bioüzemanyaggyártás élelmiszerárakra gyakorolt hatását és a becslések széles sávban mozogtak, az alapvető élelmiszerek árainak növekedését 3-75\%-kal befolyásolta. Az emberi jólét egyéb mutatóinak, mint például a bioüzemanyagok felhasználásával kapcsolatos társadalmi tőke fejlödése, a bizalom és kulturális értékek kutatása továbbra is korlátozott [MANGOYANA et al., 2013].

A biomassza alapú erőforrások széles körü termelésének köszönhetően a biomassza alapú tüzelöanyaggyártás potenciálisan több embert foglalkoztat, mint a fosszilis tüzelőanyagok elöállítása [KARTHA-LARSON, 2000]. Számos országban a bioüzemanyagipar pozitívan befolyásolta a vidék gazdaságát és a mezőgazdasági kistermelőket [RAJAGOPALZILBERMAN, 2007]. A bioüzemanyaggyártás abszolút értelemben a fajlagos tőkebefektetésre vetítve munkaintenzívebb ágazat, mint a kőolajfeldolgozás. A tanúsítási rendszerek elterjedése hozzájárulhat a kisüzemi bioüzemanyaggyártás előnyeinek garantálásához [LEWANDOWSKI - FAAIJ, 2006]. Ezenkívül a folyékony bioüzemanyaggyártás fejlesztési lehetőségeket kínál kis- és közepes méretü elektromos hálózatok kiépítésére a vidéki közösségek számára. NEUWAHL et al, (2008) általánosságban pozitív nettó foglalkoztatási hatásokat mutattak ki a mezőgazdaságban, az élelmiszeriparban és az iparban. SOLOMON (2008) szerint a helyi gazdasági hatás számos vidéki mezőgazdasági térségben viszonylag jelentős és pozitív lehet. A politikai döntéshozók a bioenergia kutatási, fejlesztési és felhasználási támogatásának foglalkoztatási hatását emelték ki [DALE et al., 2013].

A helyi gazdaságokban a bioüzemanyagok elöállításának hajtóereje gyakran a munkahelyteremtés és a gazdasági növekedés, míg a környezetvédelem és az energiabiztonság „ráadásnak" tekinthető. A közvetett foglalkoztatást képviselő munkahelyeket az inputellátók (alapanyag- és technológia) és a magasabb vásárlóerő eredményezi. A bioenergiaiparban foglalkoztatottak háztartási jövedelme a jólét mutatója [DALE et al., 2013].

Az élelmiszernövényekből előállított bioüzemanyag élelmezésbiztonsági aggodalmat keltett. Számos tanulmány elemezte a növénytermesztést és az árak alakulását. A vizsgálatok arra a következtetésre jutottak, hogy a bioüzemanyaggyártás a kezdeti becslésekhez képest sokkal kisebb hatást gyakorol az élelmiszerárakra és az USA gabonaexportjára [OLADOSU et al., 2011; POPP et al., 2016; Popp et al., 2017]. Továbbá az élelmiszerárak növekedése elmaradt a 
kőolaj globális árát követő tőzsdei nyersanyagok áremelkedésétől. A társadalmi mutatók többségét nem integrálják a biofizikai és gazdasági folyamatokba a rendszerek fenntarthatóságának holisztikus megértése érdekében, ezért a környezeti és gazdasági folyamatokba integrálható társadalmi mutatók kidolgozására van szükség [MANGOYANA et al., 2013].

Számos nemzetközi együttmüködés segíti a fenntartható bioüzemanyagok termelését és kereskedelmét. 2011-ben a fenntartható bioüzemanyagokkal foglalkozó kerekasztal (Roundtable on Sustainable Biofuels: RSB) elindította az RSB tanúsítási rendszert. A fenntarthatósági kritériumokat, valamint a biomasszára és a bioüzemanyagokra vonatkozó önkéntes vagy kötelező tanúsítási rendszert vezettek be az utóbbi időszakban, de ezek a kritériumok nem vonatkoznak a hagyományos fosszilis tüzelőanyagokra. Ha a fenntarthatósági kritériumokat kölcsönösen nem ismerik el az egyes országok globális szinten, akkor jelentős mértékben akadályozhatják a bioenergia nemzetközi kereskedelmét, ezzel együtt a fenntartható bioüzemanyag előállítás előmozdítását [VAN DAM et al., 2008]. Eddig még nem kezdtek tárgyalásokat a bioüzemanyagok tanúsításáról szóló kétoldalú megállapodásokról, annak ellenére, hogy ezt a lehetőséget megemlítették a Megújuló Energia Irányelvben (Renewable Energy Directive: RED) [EUROPEAN UNION, 2015].

Az USA-ban az Energiafüggetlenségről és -Biztonságról szóló Törvény (Energy Independence and Security Act: EISA) a bioüzemanyagokra kötelező évi mennyiséget határozott meg 2022-ig annak függvényében, hogy azok az ÜHG-kibocsátást legalább 20\%, $50 \%$ és 60\%-kal csökkentik. Amennyiben a bioüzemanyag az ÜHG-kibocsátást legalább 50\%kal csökkenti, akkor „fejlett bioüzemanyag” kategóriába esik, az ÜHG-kibocsátás legalább 60\%-os csökkentése esetében „,cellulóz alapú bioüzemanyagnak” tekinthető, végül az ÜHGkibocsátás legalább 50\%-os csökkentésénél „biomassza alapú biodízel alapanyagokról” van szó. Az új létesítményekből származó bioüzemanyagnak legalább 20\%-kal kell csökkentenie az ÜHG-kibocsátást, hogy általános megújuló tüzelőanyagnak lehessen minősíteni. Az a bioüzemanyag, amely nem felel meg ezeknek a konkrét megbízásoknak, továbbra is beleszámíthat a megújuló üzemanyagok általános szabványába (Renewable Fuel Standard: RFS). Az utóbbi kategóriába tartozó bioüzemanyag éves mennyiségét a teljes RFS és a fejlett bioüzemanyag termelés maradványaként számolják ki, amely gyakran „nem fejlett” vagy „hagyományos” bioüzemanyagnak neveznek és föleg a kukoricából elöállított etanolt foglalja magában.

Az USA-ban az RFS korlátozza az élelmiszer- és takarmánynövényekből előállítható bioüzemanyag termelését. Ezekből legfeljebb 15 milliárd gallon etanol állítható (mintegy 130 millió tonna kukorica szükséges, vagyis kukoricatermelés 35\%-a), hogy ne veszélyeztesse az élelmiszer- és takarmányipar nyersanyagellátását. 2019-ben a célértéket tovább növelték: a fejlett bioüzemanyagra 4,92 milliárd gallonra, a cellulóz alapú bioüzemanyagra 418 millió gallonra, a biomassza alapú dízelre pedig 2,1 milliárd gallonra [US EPA, 2019]. A Brazíliából származó cukornád alapú etanol és az Argentínából származó szójaolaj alapú biodízel jogosult a fejlett bioüzemanyag jelölésre.

A cukornádalapú bioüzemanyagokra vonatkozó kerekasztal-kezdeményezést Bonsurco 2008-ban hozták létre a fenntartható cukornádtermelés, -feldolgozás és -kereskedelem előmozdítása érdekében [SEIXAS, et al., 2021]. A Bonsucro célja a fenntarthatósági elöírások érvényesítésével a cukornádtermelés környezeti és társadalmi hatásainak csökkentése és a cukornádból készült termékek (etanol, a cukor és melasz) tanúsítása. 2009-ben Brazília új fenntarthatósági politikákat is bevezetett, beleértve a termelés övezetek kijelölését a cukornád termeléséhez. Brazília az egyetlen feltörekvő ország, amely az erdőirtás és a közvetett földhasználat változás megakadályozása érdekében kezdeményezte a cukornádra vonatkozó agro-ökológiai termelési övezetek meghatározását (ZAE Cana). A földhasználat gondos feltérképezésére és megtervezésére volt szükség annak eldöntéséhez, hogy mely területeken 
engedélyezik a cukornád termelését (UNICA, 2010). A program korlátozza a fejlesztési alapok igénybevételét azon cukornádtermelő gazdaság és cukor-/etanolfeldolgozó számára, amely nem tartja be a fenntarthatósági rendeletet.

A Bonsucro által kidolgozott intézkedések az EU megújuló energiaforrásokról szóló irányelvnek való megfelelés igazolására is szolgálnak. A Bonsucro két szabványt fejlesztett ki. Az egyik a „Bonsucro termelési szabvány” (Bonsucro Production Standard), amely magában foglalja a cukornád és az összes cukornádból származó termékek fenntartható előállításának kritériumait a gazdasági, társadalmi és környezeti szempontok figyelembevételével. A másik a „Bonsucro terméklánc szabvány” (Bonsucro Chain of Custody Standard), amely kiterjed az értéklánc összes fázisára az alapanyag-termeléstől kezdve a fogyasztásig bezárólag [BONSUCRO, 2014]. A „Bonsucro EU” rendszer tehát a cukornád alapú termékekre vonatkozik földrajzi hely szerinti megkötés nélkül.

Az EU megújuló energiára vonatkozó politikáját a 2009-ben elfogadott éghajlat- és energiapolitikai intézkedéscsomag (Climate Change Package: CCP) határozta meg, ugyanakkor a Megújuló Energiák Irányelv (Renewable Energy Directive: RED) is ennek a csomagnak a része. Az Európa 2020 stratégia kiemelt fontosságot tulajdonított a ,20/20/20" éghajlatenergiaügyi cél teljesítésének, amelyben az EU tagállamai vállalták, hogy 2020-ig uniós szinten legalább 20\%-kal (kedvező feltételek esetén 30\%-kal) csökkentik az ÜHG-kibocsátást, 20\%-ra emelik a megújuló energiaforrások részarányát, továbbá $20 \%$-kal növelik az energiahatékonyságot az 1990-es szinthez képest. Az egyes tagállamokra bízták, hogy a különböző megújuló források milyen kombinációjával kívánják elérni a kitüzött és kötelezően teljesítendő célokat. Azt nem határozták meg, hogy milyen legyen a megújuló energiamérleg, de az Irányelv szektorokra lebontott célokat sem tartalmaz, vagyis nem szabják meg, hogy a villamos energia vagy a hütés és a fütés hány százalékát kell zöldenergiából előállítani. Az egyetlen kivétel a közúti szállítási szektor, ahol minden tagállam számára egységesen $10 \%$ volt a cél, mivel az ÜHG-kibocsátás itt növekszik a leggyorsabban.

A megújuló energiaforrások részarányára vonatkozó 20\%-os célkitüzés az Európai Unió egészére vonatkozott, a tagállamokra a jogszabály melléklete azonban egyedi célértékeket is megfogalmazott azok gazdasági teljesítőképessége, megújuló energia potenciálja és kiotói vállalásainak figyelembevételével. A nemzeti célkitüzések jelentős mértékben eltértek az egyes tagállamok között. A célkitüzés jogilag kötelező jellege nyilvánvalóan azt eredményezi, hogy amennyiben egy tagállam nem teljesíti a célértéket, úgy az Európai Bizottság jogsértési eljárást kezdeményezhet ellene. Mivel a cél megvalósulásának tényével azonban csak 2020-ban szembesülhettünk, az utólagos jogsértési eljárás nem tekinthető hatékony megoldásnak.

Az EU megújuló energiára vonatkozó célkitűzései elvben hasonlóak az USA megújuló energiaforrásokra vonatkozó szabványaihoz, ahol a legtöbb állam kötelező vagy nem kötelező érvényü szabványokkal rendelkezik. A RED-ben a fenntarthatósági követelményeket a hagyományos folyékony bioüzemanyagokra is meghatározzák. A bioüzemanyagok nem állíthatók elő a biológiai sokféleség szempontjából nagy értéket képviselő földterületeken (elsődleges erdő és egyéb erdős terület, nagy biodiverzitású gyepterület és természetvédelmi célokra kijelölt terület), valamint magas szénkészlettel rendelkező területeken (vizes élőhely, tőzegláp és összefüggő erdőterület). Ezen kívül az üzemanyag minőségéről szóló irányelv (Fuel Quality Directive: FQD) elöírja, hogy az üzemanyaggyártók 2020-ig kötelesek 6\%-kal csökkenteni a közlekedési üzemanyagok ÜHG-kibocsátás intenzitását. Az FQD és a RED együtt a bioüzemanyagok fenntarthatóságát is szabályozza [EUROPEAN COMMISSION, 2009a; EUROPEAN COMMISSION, 2009b].

SEARCHINGER et al. (2019) bevezették a földhasználat közvetett megváltozásának (Indirect Land Use Change: ILUC) fogalmát. Ennek lényege, hogy egy természetes földterület mezőgazdasági művelésbe történő bevonása $\mathrm{CO}_{2}$ többletkibocsátással jár. A népesség növekedésének köszönhetően bővül az élelmiszerek és a bioüzemanyagok iránti igény, ezzel 
együtt a mezőgazdasági művelésbe bevont területek nagysága is. A müvelés alá vett területek általában magas kötöttszén-készletekkel rendelkeznek, ami a mezőgazdasági müvelés megkezdése után folyamatosan csökken. Ez a jelenség vezet a járulékos $\mathrm{CO}_{2}$-kibocsátáshoz. Ennek megfelelően az ILUC hatásának becslésére számos modell született [MARIYAKHAN, et al, 2020].

Mindkét irányelvet (RED, FQD) 2015-ben módosították a közvetett földhasználat változás (ILUC) irányelvvel, ennek értelmében az élelmiszer- és takarmánynövényekböl előállítható bioüzemanyag termelésére 7\%-os felső határt vezettek be. A közlekedési ágazatra vonatkozó megújuló energiaforrások célértéke $10 \%$, de ebből maximum $7 \%$ fedezhető élelmiszer- és takarmány-növényekből készített bioüzemanyagból. Továbbá a tagállamokra $0,5 \%$-os célérték került bevezetésre (nem kötelező jelleggel) a nem élelmezési célú alapanyagokból előállított fejlett bioüzemanyagra. Olaszország volt az első EU-tagállam, amely célértéket határozott meg a fejlett bioüzemanyagok elöállítására (2018-ban 0,1\%, 2019\% 0,2\% és 2020-ban 1\%). Mivel a hulladékból, maradékanyagokból (pl. állati zsír, használt étolaj) előállított bioüzemanyagok energiatartalmát kétszeresen, a közúti járművek által felhasznált megújuló energiaforrásból származó villamos energiát 2,5-szeresen kell figyelembe venni, a 7\%-os felső határ bevezetése nem befolyásolta az élelmiszernövényböl készült bioüzemanyagok előállítását.

A biomassza előállításnak mind az EU-ban, mind pedig a harmadik országokban termesztett nyersanyagok esetén fenntarthatónak kell lennie. Ezért a direktíva úgynevezett fenntarthatósági kritériumokat is megfogalmaz annak érdekében, hogy a természetvédelmi területeket és értékes erdőket megóvja, illetve, hogy ne az ÜHG-kibocsátás növelését előidéző alapanyagok termelését ösztönözze.

A bioüzemanyagok csak abban az esetben számítanak bele a kötelezettségek teljesítésébe és csak akkor támogathatók 2011 óta (a 2008 elött beüzemelt gyárak esetében 2013-tól), ha előállításuk és felhasználásuk a fosszilis energiahordozókéhoz képest legalább 35\%-kal csökkenti az ÜHG-kibocsátást. Az ÜHG-kibocsátást 2015 után már 50\%-kal kellett csökkenteni. 2018 óta 60\%-ra emelkedett az ÜHG-kibocsátás kötelező csökkentése a 2015. október 5 után üzembe helyezett gyárak esetében (a korábban üzembe helyezett gyárak számára $50 \%$ az elöírás). A nyersanyagok előállítására is fenntarthatósági kritériumokat határoztak meg, beleértve a földhasználat változásából eredő ÜHG-kibocsátás változását is. Összességében a termesztésből, feldolgozásból és szállításból származó ÜHG-kibocsátást veszik figyelembe. Sőt, szociális (munkavédelmi) kritériumokat is elöírtak, ami az exportőr országok (pl.: Brazília) számára nehezíti meg a bioüzemanyag kivitelét az EU-ba. Meghatározták továbbá, hogy az összes bioüzemanyag egyre nagyobb hányada (konkrét mérték nélkül) az ún. második generációs bioüzemanyag legyen, amelyek energiatartalmát kétszeresen számítják be a tagállami kötelezettségekbe [EUROPEAN COMMISSION, 2019].

2017 februárjában megjelent a RED felülvizsgálatának (REDII) javaslata, amely 2030 után 3,8\%-ra tervezte csökkenteni az élelmiszer- és takarmánynövényekből elöállított bioüzemanyag bekeverési arányát [EUROPEAN COMMISSION, 2017a]. Az EU-ban a bioüzemanyag előállító vállalatok tiltakoztak a Bizottság javaslata ellen, mivel az szerintük a tudományos tényekkel és gazdasági racionalitással egyaránt szembe megy. A felülvizsgálat keretében a Bizottság végül is azt határozta meg, hogy a mai viszonyokhoz képest 2030 után milyen energiaellátási szerkezetet tervez az EU-ban a klímavédelmi vállalások teljesítése és új munkahelyek teremtése érdekében. A hatályos szabályozás felülvizsgálata arról szól, hogy az első generációs bioüzemanyagokkal szemben a fejlettebb generációs bioüzemanyagokat részesítik előnyben. A fejlettebb generációstechnológiát nem az első generációs technológia rovására, hanem annak kiegészítéseként indokolt elterjeszteni.

A RED II ambiciózus célokat tüzött ki a cellulóz alapanyagból előállított bioüzemanyagokra, de ezeknek a fejlett bioüzemanyagoknak a piaci bevezetése eddig korlátozott volt (1\%). A RED II fenntarthatósági kritériumai 2023-ig a 2019. évi szinten befagyasztották a magas kockázatú 
ILUC területeken (ahol a közelmúltban erdöirtás történt vagy a gyepterületeket szántóterületként hasznosítják) előállított pálmaolajból készült biodízel felhasználásának beszámítását a célérték teljesítésében, sőt 2030-ig fokozatosan nullára csökkentik ezt a lehetőséget. Az ILUC pálmaolaj vagy abból készült biodízel behozatala az EU-ba tehát továbbra is lehetséges, de az nem számítható be a RED II célkitüzéseinek teljesítéséhez. A biodízelgyártásban tehát a pálmaolaj alacsony ILUC-kockázatú alapanyagként való felhasználása tanúsítást igényel. Ez befolyásolja a pálmaolaj és ezzel együtt egyes szójatermékek (helyettesítő termék) iránti kereslet alakulását. Az elektromos autók növekvő részesedése csökkentheti az összes folyékony üzemanyagfogyasztást, ezzel párhuzamosan a bioüzemanyag felhasználást is [EUROPEAN COMMISSION, 2019; OECD/FAO 2019].

2019-ben a Bizottság felhatalmazáson alapuló jogi aktust fogadott el a magas és alacsony ILUC-kockázatú bioüzemanyagokról annak érdekében, hogy előmozdítsa a fejlett bioüzemanyagok és más alacsony ÜHG-kibocsátású üzemanyagok (megújuló villamos energia, nem biológiai alapú folyékony és gáznemü közlekedési üzemanyagok) termelését. A fejlett bioüzemanyagok nagyon kis piaci részesedéssel rendelkeznek (1\%) az EU-ban, de jelentős a termelésnövelés lehetősége. A REDII azt is megállapítja, hogy tudományos értékelésre van szükség a fejlett bioüzemanyagok alapanyagbázisának kibővítéséhez [EUROPEAN COMMISSION, 2019].

A RED II elöirja, hogy 2030-ban a tagállamokban együttesen az EU teljes bruttó energiafogyasztásának legalább 32\%-át megújuló energia képezze. A Bizottság e célkitüzés értékelése alapján 2023-ig jogalkotási javaslatot terjeszt elő annak esetleges növelése céljából a termelési költségek, az uniós energiafogyasztás és az ÜHG-kibocsátásra vonatkozó nemzetközi kötelezettségteljesítés alakulásának függvényében. A közlekedési szektorra 14\%os célértéket határoztak meg (a RED I 10\%-os célértékével szemben). 2030-ra az élelmiszerés takarmánynövényekből előállítható bioüzemanyag termelésére bevezetett 7\%-os felső határ érvényben marad (eredeti javaslat a 7\% felső határ 3,8\%-ra való csökkentése volt), vagyis a 14\%-os célérték fele teljesíthető élelmiszer célú növényekböl. Ugyanakkor a 14\%-os célértéken belül 3,5\%-os részarányt kell elérni a fejlett bioüzemanyagoknak, de ezen bioüzemanyagok energiatartalmát kétszeresen veszik figyelembe. A lignocellulóz alapú bioüzemanyag (bioetanol) célértéke legalább 1,75\% (kalkulált energiatartalom 3,5\%), a hulladékból (használt étolaj és állati zsírok) előállított bioüzemanyag (biodízel) célértéke pedig legalább 1,7\% (kalkulált energiatartalom 3,4\%). Ez azt jelenti, hogy a fejlett bioüzemanyag tényleges részaránya 3,5\% lesz a kalkulált 7\% helyett. A zöld áram a közúti közlekedésben 4,0-szeresen, a vasúti közlekedésben 1,2-szeresen számolható el. További követelmény, hogy a 2021. január 1 után üzembe helyezett bioüzemanyaggyárak esetében 65\%-ra emelkedett az ÜHG-kibocsátás kötelezö csökkentése. 2018 óta a 2015. október 5 után üzembe helyezett gyárakra $60 \%$ vonatkozik [EUROPEAN COMMISSION, 2018].

Az EU tagállamai arra kötelezték a bioüzemanyag szolgáltatókat, hogy a bioüzemanyaggyártók az érintett tüzelőanyag életciklusa alatt elért ÜHG-kibocsátást akár 10\%kal (kötelezően 6\%-kal) csökkentsék a 2010. évi alapértékhez képest. Az EU célja, hogy 2050ig a közlekedés ÜHG kibocsátása 60\%-kal csökkenjen az 1990-es szinthez viszonyítva. Időközben az EU a nettó nulla ÜHG-kibocsátás célértéket határozott meg 2050-re, vagyis tovább szigorította az ÜHG kibocsátására vonatkozó célokat, ráadásul a közlekedés ÜHG kibocsátása továbbra is folyamatosan nő [VAN GRINSVEN - KAMPMAN, 2015].

Egyes tagállamok teljes mértékben átültették az ILUC-irányelvet (bioüzemanyag-előállítás okozta közvetett földhasználat-változás) és 2020-ig 0,5\% célértéket határoztak meg a fejlett bioüzemanyagokra, míg más tagállamok $0,5 \%$-ot meghaladó vagy annál alacsonyabb célkitüzést írtak elő. Magyarország, Svédország és az Egyesült Királyság nem állapított meg célértéket a fejlett bioüzemanyagokra. Az üzemanyag minőségéről szóló irányelv (FQD) az EU valamennyi tagállamában megvalósult. Büntetést szabhatnak ki, ha a bioüzemanyaggyártók 
nem teljesítik kötelezettségüket, de Lettországban és Dániában nincs érvényben büntetörendszer [EPURE, 2018].

Ha a bioüzemanyagok átlagos ÜHG kibocsátásának intenzitása az ILUC irányelv hatására csökken, az FQD célkitüzés elméletileg könnyebben teljesíthető is. Az EU tagállamai vállalták, hogy 2020-ig uniós szinten 20\%-kal csökkentik az 1990-es szinthez képest az üvegházhatást okozó gázok kibocsátását, továbbá 20\%-ra növelik a megújuló energiaforrások részarányát. A megújuló energiákra vonatkozó uniós irányelv (Renewable Energy Directive: RED) elöírta, hogy 2020-ra az EU-ban el kell érni a 10\%-os megújuló energia részarányt a közlekedési szektorban. Az Európai Bizottság nem változtatta meg a közlekedésben a megújuló energiaforrások 2020-ig elérendő (10\%-os) részarányát a teljesítésben, de ebböl a 10\%-ból maximum 7\% fedezhető élelmiszer- és takarmánynövényekből készített bioüzemanyagból [EUROPEAN COMMISSION, 2017b]. Ennek segítségével tehát az EU-ban is korlátozzák az élelmiszernövényekből (föleg gabonából, cukorrépából és olajnövényekből) előállított bioüzemanyag mennyiségét. Az előzetes kalkulációk alapján az EU és tagállamai 20\%-ra növelték a megújuló energiaforrások részarányát, ezen belül 10\%-ra a közlekedési szektorban. Ehhez hozzájárult az is, hogy 2020-ban a COVID-19 hatására visszaesett a globális energiafogyasztás.

A RED elfogadása óta több mezőgazdasági földterületet vontak ki a termelésből, mint amennyi területre szükség lenne az EU-ban az összes bioüzemanyag elöállításához. Az élelmezési célú alapanyagokból előállított első generációs bioüzemanyagok hatása a földhasználat változásra alacsonyabb, ha figyelembe vesszük a bioüzemanyaggyártás melléktermékeit, elsősorban a fehérjetakarmányt, mert így csökken a nettó földhasználat [LANGEVELD et al., 2014]. A bioüzemanyagipar alapanyagainak termesztése potenciálisan negatív környezeti hatást eredményezhet, amely helyspecifikus és az alkalmazott mezőgazdasági gyakorlattól függ, de sem a helyspecifikus adatok, sem pedig a bioüzemanyag előállításához felhasznált alapanyagok termesztésének helyi környezeti hatásaival kapcsolatos adatok nem állnak rendelkezésre. A bioüzemanyagipar által felhasznált alapanyagok a teljes mezőgazdasági tevékenység kis hányadát teszik ki, ezért az ehhez kapcsolódó környezeti hatások jelentéktelenek [EUROPEAN COMMISSION, 2019].

Az EU célkitüzése, hogy a bioüzemanyagokhoz kapcsolódó termelési és ellátási lánc egésze fenntartható legyen, ezért vezette be a világon a legszigorúbb fenntarthatósági elöírásokat. A Bizottság által elismert rendszerek biztosítják e szigorú előírások betartását. Az állami támogatás megszerzéséhez vagy a megújuló energiaforrásokra vonatkozó nemzeti célkitűzésekbe való beszámításhoz az EU-ban használt bioüzemanyagoknak - helyileg előállított vagy importált üzemanyagok - meg kell felelniük a fenntarthatósági kritériumoknak. Az EU néhány tagállama nemzeti önkéntes rendszert hozott létre, míg más tagállamok az Európai Bizottság által elfogadott önkéntes rendszerekre támaszkodnak. A fenntarthatósági kritériumok sikeresen csökkentik a bioüzemanyagokhoz kapcsolódó közvetlen környezeti hatások kockázatát, függetlenül attól, hogy azokat az EU-ban állítják elő, vagy harmadik országokból importálják-e. Az önkéntes rendszerek váltak a fő eszközzé az EU bioüzemanyagfenntarthatósági kritériumainak való megfelelés bizonyítására. A bioüzemanyagok fenntarthatóságáról meg kell bizonyosodni a tagállamok által végzett ellenőrzések vagy az Európai Bizottság által elfogadott önkéntes rendszerek segítségével. 2019-ben az EU-ban már több mint egy tucat önkéntes rendszert ismertek el a RED I fenntarthatósági kritériumainak való megfeleléséhez [EUROPEAN COMMISSION, 2019].

A szóban forgó rendszerek keretében ellenőrzik, hogy a bioüzemanyagokat hol és hogyan állították elő. Ha egy termék esetében teljesülnek az önkéntes rendszer szabályai, a termék a rendszer keretében tanúsítványt kaphat. A Bizottság által elvégzett aprólékos értékelés után az alábbi fő rendszerek részesültek elismerésben: Nemzetközi Fenntarthatósági és Szén-dioxidkibocsátási Tanúsítvány (International Sustainability Carbon Certification: ISCC) államilag 
finanszírozott német rendszer (valamennyi bioüzemanyag-típusra kiterjed), Bonsucro EU (a cukornádalapú bioüzemanyagokra vonatkozó kerekasztal-kezdeményezés, amely Brazíliára helyezi a hangsúlyt) RTRS EU RED (a szójaalapú bioüzemanyagokra vonatkozó kerekasztalkezdeményezés, amely Brazíliára és Argentínára helyezi a hangsúlyt) RSB EU RED (valamennyi bioüzemanyag-típusra kiterjedő kerekasztal-kezdeményezés) Biomass Biofuel Sustainability voluntary scheme (2BSvs) (biomasszára és bioüzemanyagra vonatkozó önkéntes fenntarthatósági rendszer) RSBA (az Abengoa spanyol feldolgozó ellátási láncát lefedő ipari rendszer) Greenergy (a Greenergy brit társaság rendszere, amely a Brazíliából származó cukornádból előállított etanolra vonatkozik). A RED II további szigorítást is magában foglal a fenntarthatóság vonatkozásában [EUROPEAN COMMISSION, 2019].

\section{Kilátások}

Az élelmiszerválság elsődleges oka a kereslet növekedése és a kínálat fluktuációja, mivel az élelmiszerek kereslet ár- és jövedelem rugalmassága kicsi, de termékenként és országonként változik. A kínálati oldalon a mezőgazdasági földterületek csökkenése (városiasodás és ipari területek növekedése) az időjárási tényezők (vízhiány, áradás) ellátási zavarokhoz vezethetnek. A spekuláció fontos szerepet tölt be a piaci likviditás szempontjából, ugyanakkor növelheti az árak volatilitását is. A növekvő olajáraknál egyre inkább előtérbe került az energiabiztonság kérdése, ami a bioüzemanyag-gyártás további növelését eredményezte. A bioüzemanyaggyártás világszerte egyelőre a nemzeti energiapolitikáknak megfelelően elsősorban a belső piac igényeit elégíti ki, ennek ellenére az utóbbi évtizedben megfigyelhető volt az exportra termelés is. A világ két legnagyobb bioüzemanyag piaca az USA és Brazília, a nemzetközi beruházások fö kedvezményezettjei pedig Brazília és Európa. Brazília azért vonzó befektetői célpont, mert bőséges nyersanyaggal és feldolgozóipari kapacitással, valamint potenciális exportpiaccal rendelkezik. Az USA és Brazília komoly nettó exportőr a bioüzemanyagipar által felhasznált nyersanyagokból, ezzel szemben az EU a világ első számú biodízelgyártója, pedig nettó importőr olajnövényekböl és növényolajból.

A globális biodízelgyártásban továbbra is a repce és szója lesz a meghatározó nyersanyag. Európa, Észak- és Dél-Amerika maradnak a biodízelgyártás vezető régiói, ugyanis a világ fő repce- és szójatermelő országairól van szó. A növekvő biodízelgyártás több szójaolajat igényel, ugyanakkor Európában a növényolaj kínálata egyre korlátozottabb lesz. Európa marad a növényolaj/olajnövény fő importöre. Az alternatív nyersanyagok, mint a jatropha és a manióka jelentősége nő, különösen a nyersanyagellátási problémával küszködő Kínában és Indiában.

Brazília és az USA bioüzemanyag-előállításának szabályozását ambiciózus célkitüzések jellemzik. Brazília az egyetlen ország, ahol víztartalmú (hydrous) és tiszta (anhydrous) etanolt használnak. Az USA az egyetlen ország a világon, ahol a második és harmadik generációs üzemanyagokra is meghatároztak célértéket (térfogatra vonatkoztatva). Ezzel szemben az EUban a megújuló energiaforrások irányelve szigorú környezetvédelmi és fenntarthatósági feltételeket ír elő a bioüzemanyag-gyártásra (elsősorban a nyersanyagok fenntartható termelésére és az üvegházhatású gázok kibocsátásának csökkentésére). Az EU az egyetlen országcsoport a világon, ahol az ÜHG-kibocsátás csökkentésére célértéket határoztak meg.

Mivel a tagállamok eltérő potenciállal rendelkeznek a megújuló energiaforrások terén, az Európai Bizottság önkéntes alapon engedélyezi a megújuló energiák uniós kereskedelmét. Ez egyrészt lehetővé teszi az ilyen energiaforrásokban szegény tagországoknak, hogy olyan más tagállamokban finanszírozzanak beruházásokat, ahol a zöldenergia előállításának a költségei a legalacsonyabbak. Cserébe saját teljesítésükbe számíthatják bele az így előállított „zöld” energiát. A kereskedelem egy másik formája lehet, ha a cégek egy másik országban vásárolhatnának zöldigazolványokat (úgynevezett eredetgaranciát), ha a piaci kínálatot nyújtó tagország már elérte/túllépte a számára elöírt célt. Európán kívüli uniós beruházásból származó 
„zöld” energia is elszámolható lesz, amennyiben a szóban forgó ország is az Unióhoz hasonló standardokkal rendelkezik. A 2020. évi nemzeti célkitüzéseket nem teljesítő tagországokat szankcionálják az elfogadott pénzügyi bírságok rendszere alapján. Az ezekből származó pénz egy olyan alapba fog befolyni, amiből azokat a tagországokat jutalmazzák, amelyek eleget tesznek a nemzeti célkitüzéseknek.

A második generációs technológia piaci bevezetésére még várni kell. Továbbá ma is korlátozott még a cellulózalapú nyersanyagok felhasználása a bioetanolgyártásban, valamint az állati zsírok és használt sütőolaj szerepe a biodízelgyártásban. Megfelelő szabályozás és fenntarthatósági kritériumrendszer lehetővé teszi, hogy a bioüzemanyagok hozzájáruljanak a fenntartható fejlődéshez [OLÁH et al., 2020].

A rendelkezésre álló növényi biomassza igen sokrétü, különböző módon dolgozható fel. A hasznosítás területén a technológiák által nyújtott lehetőségek sora egyre kifinomultabb eszközökkel folyamatosan gyarapodik. Ehhez hozzájárult a természettudomány és a biotechnológia fejlődése, mert ezek segítségével létrehozott környezetkímélő technológiák a hatékonyabb élelmiszertermelés mellett új termékek előállítását is lehetővé tették. Jelenleg a „zöld kémia” iparágban az eltüzelés, a pirolizálás, a biogáz-, bioetanol- és a biodízel előállítás területe érdemel említést. De a növényi biomassza ma az energetikai felhasználás mellett különböző biomassza alapú kémiai alapanyagok előállítására is alkalmas.

Az EU-ban a bioüzemanyagipar elsősorban Dél-Amerikával és Észak-Amerikával versenyez. Közel két évtizede húzódtak már a szabadkereskedelmi tárgyalások az Európai Unió és Dél-Amerika (Mercosour országok) között, míg 2019-ben az EU négy Mercosour tagországgal (Argentína, Brazília, Paraguay and Uruguay) aláírta a szabadkereskedelmi megállapodást. Ez kihívásokat jelent az EU számára, mert a dél-amerikai piac legfontosabb termékei többek között az etanol (Brazília) és biodízel (Argentína) a cukor, az izocukor, a méz, valamint a szarvasmarha- és baromfihús mellett.

Az EU direktíva kötelezővé tette, hogy 2020-ra a 10 térfogat \%-ot érje el a megújuló energia a közlekedési szektorban, beleértve a bioüzemanyagot, a biogáz üzemű és elektromos autót, vonatot vagy a hibrid autót. Ez az arány az EU-ban 2018-ban 8,0\% volt, beleértve a biodízelgyártás alapanyagául szolgáló használt étolajat és állati zsírokat is. Az előzetes adatok alapján a $10 \%$-os arány teljesítése nem okozott gondot. Ehhez az is hozzájárult, hogy a Covid19 járvány hatására drasztikusan csökkent az fosszilis eredetü üzemanyagfogyasztás, de nőtt a megújuló energia felhasználása a nap-, szél- és vízenergia előállítás bővülésének köszönhetően.

A megújuló energia előretörése bizonyos problémákat is támasztott az ellátásbiztonság szempontjából. A fejlett gazdaságokban az áramszünetek egyik fö oka, hogy a rendszer nem mindig képes kezelni az energiaáramlás hirtelen változásait, de számos egyéb hálózati probléma is felléphet. A jelenlegi helyzetben az alacsony fogyasztás bővülő nap- és szélenergiatermeléssel párosul, ezáltal az időjárásfüggő megújuló energia aránya megnőtt a villamosenergia-termelésben, ami nagyobb rugalmasságot követel meg a rendszertől az energiaellátás fenntartása érdekében. Ugyanakkor a rendszer elérhető rugalmassága korlátozott, részben a keresleti oldalon a szabályozásban részt venni képes ipari üzemek jelentős részének leállítása miatt, miközben az alacsony villamosenergia árak miatt a kínálati oldalon leszabályozható erőmüvek száma is csökkent. Ahogyan az energiaipar pénzügyi kihívásai fokozódnak, a leállított szabályozási kapacitás újraindításának költsége jelentős energiabiztonsági aggállyá válhat, amint a gazdaság és a villamosenergia-fogyasztás ismét növekedésnek indul. A nagy gazdaságok villamosenergia-rendszerei eddig megbízhatóan teljesítettek, de a továbbiakban is a rendszerüzemeltetök, szabályozók és kormányok folyamatos éberségére van szükség [IEA, 2020a].

A Covid-19 válság a zöld energia további térhódítását is befolyásolja. A globális $\mathrm{CO}_{2-}$ kibocsátás ugyan abszolút értékben 2020-ban visszaesett, de az emisszió csökkenése átmeneti jelenség. A korábbi gazdasági válságok után megugrott az ÜHG-kibocsátás, sőt az emisszió 
legnagyobb éves növekedésére pedig éppen a legutóbbi 2008-as gazdasági világválságot követően, 2010-ben került sor. A Covid 19 okozta gazdasági visszaesés hatására villamosenergia ágazatban is visszaesett a kereslet 2020-ban a gyárak, az irodaházak, s szállodák és üzletek villamos energia fogyasztása természetesen csökkent, ugyanakkor a háztartások fogyasztása emelkedett. Az energiahordozók piacán az árak csökkentek, legalábbis rövid távon. A fosszilis tüzelőanyagok iránt mutatkozó kereslet óriási visszaesésével szemben a megújuló energiaforrások termelését nem vagy alig befolyásolta a koronavírus-járvány [IEA, 2020b].

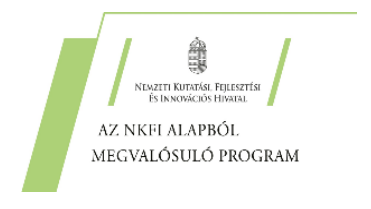

„A 132805 számú projekt a Nemzeti Kutatási Fejlesztési és Innovációs Alapból biztosított támogatással, a K_19 pályázati program finanszírozásában valósult meg"

\section{Hivatkozott források}

1. BONSUCRO (2014): The global sugarcane platform: Bonsucro production standard including Bonsucro EU production standard. London: Bonsucro. Forrás: https://www.bonsucro.com/wp-content/uploads/2017/01/Bonsucro-Production-

Standard-4.1.pdf. Letöltés dátuma: 2020. 12. 31.

2. BRITZ, W. - HERTEL, T.W. (2011): Impacts of EU biofuels directives on global markets and EU environmental quality: an integrated PE, global CGE analysis. Agriculture, Ecosystems \& Environment, 142(1-2), 102-109. DOI: 10.1016/j.agee.2009.11.003

3. BUCHHOLZ, T.S. - VOLK, T. A. - LUZADIS, V.A. (2007): A participatory systems approach to modeling social, economic, and ecological components of bioenergy. Energy Policy, 35(12), 6084-6094. DOI: 10.1016/j.enpol.2007.08.020

4. CAMPBELL, J.E. - LOBELL, D.B. - GENOVA, R.C. - FIELD, C.B. (2008): The global potential of bioenergy on abandoned agricultural lands. Environmental Science \& Technology, 42(15), 5791-5794. DOI: 10.1021/es800052w

5. CORREA, D.F. - BEYER, H.L. - FARGIONE, J.E. - HILL, J.D. - POSSINGHAM, H.P. - THOMAS-HALL, S.R. - SCHENK, P. M. (2019): Towards the implementation of sustainable biofuel production systems. Renewable and Sustainable Energy Reviews, 107(June), 250-263. DOI: 10.1016/j.rser.2019.03.005

6. DALE, V.H. - EFROYMSON, R.A. - KLINE, K L. - LANGHOLTZ, M. H. - LEIBY, P.N. - OLADOSU, G.A. - HILLIARD, M.R. (2013): Indicators for assessing socioeconomic sustainability of bioenergy systems: a short list of practical measures. Ecological Indicators, 26., 87-102. DOI: 10.1016/j.ecolind.2012.10.014

7. DE OLIVEIRA, M.E.D. - VAUGHAN, B.E. - RYKIEL, E.J. (2005): Ethanol as fuels: energy, carbon dioxide balances, and ecological footprint. BioSci, 55(8), 593-602. DOI: 10.1641/0006-3568

8. EGGERS, J. - TRÖLTZSCH, K. - FALCUCCI, A. - MAIORANO, L. - VERBURG, P.H. - FRAMSTAD, E. - DELBAERE, B. E. N. (2009): Is biofuel policy harming biodiversity in Europe? GCB Bioenergy, 1., 18-34. DOI: 10.1111/j.17571707.2009.01002.x 
9. EPURE (2018): Overview of biofuel policies and markets across the EU-28. 102. p. Euroepan Renewable Ethanol. Forrás: https://epure.org/media/1757/180903-def-repoverview-of-biofuel-policies-and-markets-across-the-eu-28.pdf. Letöltés dátuma: 2020. 12. 31 .

10. EUROPEAN COMMISSION (2009a): Directive 2009/28/EC of the European Parliament and of the Council of 23 April 2009 on the promotion of the use of energy from renewable sources and amending and subsequently repealing Directives 2001/77/EC and 2003/30/EC, 11, 39-85. Forrás: https://eurlex.europa.eu/LexUriServ/LexUriServ.do?uri=OJ:L:2009:140:0016:0062:EN:PDF Letöltés dátuma: 2020. 12.31.

11. EUROPEAN COMMISSION (2009b): Directive 2009/30/EC of the European Parliament and the Council of 23 April 2009 amending Directive 98/70/EC as regards the specification of petrol, diesel and gas-oil and introducing a mechanism to monitor and reduce greenhouse gas emissions and amending Council Directive 1999/32/EC as regards the specification of fuel used by inland waterway vessels and repealing Directive 93/12/EEC (OJ L L 140/88). Forrás: http://eurlex.europa.eu/LexUriServ/LexUriServ.do?uri=OJ:L:2009:140:0088:0113:EN:PDF Letöltés dátuma: 2020. 12.31.

12. EUROPEAN COMMISSION (2017a): Review of the EU bioeconomy strategy and its action plan - Expert group report - Study. Publications Office of the European Union, Luxembourg DOI: $10.2777 / 149467$

13. EUROPEAN COMMISSION (2017b): Proposal for a Directive of the European Parliament and of the Council on the promotion of the use of energy from renewable sources (recast). https://op.europa.eu/en/publication-detail/-/publication/3eb9ae57-faa611e6-8a35-01aa75ed71a1/language-en (letöltés dátuma: 2020. 12.31)

14. EUROPEAN COMMISION (2018): COM(2018) 392 final2018/0216 (COD). Proposal for a Regulation of the European Parliamanet and of the Council establishing rules on support for strategic plans to be drawn up by Member States under the Common agricultural policy (CAP Strategic Plans) and financed by the European Agricultural Guarantee Fund (EAGF) and by the European Agricultural Fund for Rural Development (EAFRD) and repealing Regulation (EU) No1305/2013 of the European Parliament and of the Council and Regulation (EU) No 1307/2013 of the European Parliament and of the Council, 1-143.p. $\quad$ Forrás: https://eur-lex.europa.eu/legalcontent/EN/TXT/?uri=COM\%3A2018\%3A392\%3AFIN. Letöltés dátuma: 2020. 12. 31.

15. EUROPEAN COMMISSION (2019): Report from the Commission to the European Parliamanet, the Council, the Euroepan and Social Committee of the Regions, Renewable Energy Progress Report. Brussels, 9.4.2019 COM(2019) 225 final, European Commission. $\quad$ Forrás: https://eur-lex.europa.eu/legalcontent/EN/TXT/?uri=COM:2019:225:FIN. Letöltés dátuma: 2020. 12. 31.

16. EUROPEAN UNION (2015): Directive (EU) 2015/1513 of the European Parliament and of the Council of 9 September 2015 amending Directive 98/70/EC relating to the quality of petrol and diesel fuels and amending Directive 2009/28/EC on the promotion of the use of energy from renewable sources (OJ L 239/1). Forrás: http://eurlex.europa.eu/legal-content/en/TXT/?uri=CELEX\%3A32015L1513 Letöltés dátuma: 2020. 12. 31.

17. FRÓNA, D. - SZENDERÁK, J. - HARANGI-RÁKOS, M. (2019): The challenge of feeding the world. Sustainability, 11(20), 5816. DOI: 10.3390/su11205816

18. GOPALAKRISHNAN, G. - NEGRI, M.C. - WANG, M. - WU, M. - SNYDER, S.W. LAFRENIERE, L. (2009): Biofuels, land, and water: a systems approach to sustainability. Environmental Science \& Technology, 43., 6094-6100. DOI: 10.1021/es900801u 
19. GROOM, M.J. - GRAY, E.M. - TOWNSEND, P.A. (2008): Biofuels and biodiversity: principles for creating better policies for biofuel production. Conservation Biology, 22., 602-609. DOI: 10.1111/j.1523-1739.2007.00879.x

20. HARANGI-RÁKOS, M. - POPP, J. - OLÁH, J. (2017): A bioüzemanyag előállítás globális kihívásai. Journal of Central European Green Innovation, 5(4), 13-31.

21. HARANGI-RÁKOS, M. - POPP, J. - OLÁH, J. (2018): A biomassza energetikai és egyéb célú felhasználása. Magyar Energetika, 25(2), 8-16.

22. HARSÁNYI, E. - BASHIR, B. - ALMHAMAD, G. - HIJAZI, O. - MAZE, M. ELBELTAGI, A. - SZABÓ, S. (2021): GHGs Emission from the Agricultural Sector within EU-28: A Multivariate Analysis Approach. Energies, 14(20), 6495. DOI: 10.3390/EN14206495

23. HELLMANN, F. - VERBURG, P. H. (2010): Impact assessment of the European biofuel directive on land use and biodiversity. Journal of Environmental Management, 91(6), 1389-1396. DOI: 10.1016/j.jenvman.2010.02.022

24. IEA (2020a): Global Energy Review 2020. The impacts of the Covid-19 crisis on global energy demand and $\mathrm{CO}_{2}$ emissions. International Energy Agency, pp. 1-56. Forrás: https://www.iea.org/reports/global-energy-review-2020. Letöltés dátuma: 2020. 12. 31

25. IEA (2020b): Covid-19 crisis will wipe out demand for fossil fuels, says IEA. International Energy Agency. Forrás: https://www.theguardian.com/business/2020/apr/30/covid-19-crisis-demand-fossilfuels-iea-renewable-electricity. Letöltés dátuma: 2020. 12. 31.

26. IGNACIUK, A. (2006): Economics of multifunctional biomass systems. Forrás: https://www.semanticscholar.org/paper/Economics-of-multifunctional-biomasssystems-Ignaciuk/2aecbbc74f0178d0f9373ddf12abc87c854d0d0a Letöltés dátuma: 2020. 12. 31.

27. KARTHA, S. - LARSON, E.D. (2000): Bioenergy primer: Modernized biomass energy for sustainable development, Technical Report UN Sales Number E.00.III.B.6, United Nations Development Programme. 1 United Nations Plaza, New York, NY 10017, USA. Forrás:https://www.undp.org/content/dam/aplaws/publication/en/publications/environm ent-energy/www-ee-library/sustainable-energy/bioenergy-primer-modernised-biomassenergy-for-sustainable-development/Bioenergy\%20Primer_2000.pdf. Letöltés dátuma: 2020. 12. 31.

28. KAZAMIA, E. - SMITH, A.G. (2014). Assessing the environmental sustainability of biofuels. Trends in Plant Science, 19., 615-618. DOI: 10.1016/j.tplants.2014.08.001

29. KHAN, S.R. - YUSUF, M. - KHAN, S.A. - ABBASY, R. (2010): Biofuels trade and sustainable development: the case of sugarcane bioethanol in Pakistan. Biofuels Production. Trade and Sustainable Development Energy Policy, 35., 3550-3570.

30. LADANAI, S. - VINTERBÄCK, J. (2009): Global potential of sustainable biomass for energy (No. 013). Forrás: https://worldbioenergy.org/uploads/WBA_Global\%20Potential.pdf

31. LANGEVELD, J.W.A. - DIXON, J. - VAN KEULEN, H. - QUIST-WESSEL, P.M.F. (2014): Analyzing the effect of biofuel expansion on land use in major producing countries: Evidence of increased multiple cropping. Biofuel Bioprod. Biorefin, 8., 49-58. DOI: $10.1002 / b b b .1432$

32. LÁSZLOK, A. - TAKÁCS-GYÖRGY, K. - TAKÁCS, I. (2020): Examination of first generation biofuel production in some selected biofuel producing countries in Europe: A case study. Agricultural Economics-Zemedelska Ekonomika, 66(10), 469-476. DOI:10.17221/237/2020-AGRICECON 
33. LEWANDOWSKI, I. - FAAIJ, A.P.C. (2006): Steps toward the development of a certification system for sustainable bioenergy trade. Biomass Bioenergy, 30., 83-104. DOI: $10.1016 /$ j.biombioe.2005.11.003

34. LORA, E.E.S. - PALACIO, J.C.E. - ROCHA, M.H. - RENÓ, M.L.G. - VENTURINI, O.J. - DEL OLMO, O.A. (2011): Issues to consider, existing tools and constraints in biofuels sustainability assessments. Energy, 36., 2097-2110. DOI: https://doi.org/10.1016/j.energy.2010.06.012

35. LUZADIS, V.A. - VOLK, T.A. - BUCHHOLZ, T.S. (2008): Using a systems approach to improve bioenergy sustainability assessment. In: Solomon, B.D. - Luzadis, V.A. (Eds.): Renewable Energy From Forest Resources in the United States. Oxford, UK: Routledge, pp. 196-209.

36. MAGDA, R. - TÓTH, J. (2019): The connection of the methanol economy tot he concept of the circular economy and its impact on sustainability. Visegrad Journal on Bioeconomy and Sustainable Development, 8(2), 58-62. DOI: 10.2478/vjbsd-2019-0011

37. MANGOYANA, R.B. - SMITH, T.F. - SIMPSON, R. (2013): A systems approach to evaluating sustainability of biofuel systems. Renewable and Sustainable Energy Reviews, 25., 371-380. DOI: 10.1016/j.rser.2013.05.003

38. MARIYAKHAN, K. - MOHAMUED, E. A. - ASIF KHAN, M. - POPP, J. - OLÁH, J. (2020): Does the level of absorptive capacity matter for carbon intensity? Evidence from the USA and China. Energies, 13(2), 407. DOI: 10.3390/en13020407

39. MCBRIDE, A.C. - DALE, V.H. - BASKARAN, L.M. - DOWNING, M.E. - EATON, L.M. - EFROYMSON, R.A. - GARTEN, C.T. - JR, KLINE, K. L. - JAGER, H.I. MULHOLLAND, P.J. - PARISH, E.S. - SCHWEIZER, P.E. - STOREY, J.M. (2011): Indicators to support environmental sustainability of bioenergy systems. Ecological Indicators, 11., 1277-1289. DOI: 10.1016/j.ecolind.2011.01.010

40. MEYER, N. - MAGDA, R. - BOZSIK, N. (2021): The role of renewable energies in the new EU member states. Journal of Eastern European and Central Asian Research, 8(1), 18-25. DOI: 10.15549/jeecar.v8i1.536

41. MOHAMMED, S. - GILL, A. R. - ALSAFADI, K. - HIJAZI, O. - YADAV, K. K. KHAN, A. H. - HARSANYI, E. (2021): An overview of greenhouse gases emissions in Hungary. Journal of Cleaner Production, 127865. DOI: 10.1016/j.jclepro.2021.127865

42. NEUWAHL, F. - LÖSCHEL, A. - MONGELLI, I. - DELGADO, L. (2008): Employment impacts of EU biofuels policy: Combining bottom-up technology information and sectoral market simulations in an input-output framework. Ecological Economics, 68, 447-460. DOI: 10.1016/j.ecolecon.2008.04.018

43. OECD (2009): The Bio-economy to 2030: Designing a Policy Agenda, Main Findings. Organisation for Economic Cooperation and Development. Letöltés dátuma: 2020. 12. 31. DOI: $10.1787 / 9789264056886-$ en

44. OECD/FAO (2019): Agricultural Outlook 2019-2028. OECD Publishing, Organisation for Economic Co-operation and Development and Food and Agriculture Organization of the United Nations, Rome. Letöltés dátuma: 2020. 12. 31. DOI: 10.1787/agr_outlook2019-en

45. OLADOSU, G. - KLINE, K. - URIA-MARTINEZ, R. - EATON, L. (2011): Sources of corn for ethanol production in the United States: a decomposition analysis of the empirical data. Bioprod Bioref, 5(6). 640-653. DOI: 10.1002/bbb.305

46. OLÁH, J. - LENGYEL, P. - BALOGH, P. - HARANGI-RÁKOS, M. - POPP, J. (2017): The role of biofuels in food commodity prices volatility and land use. Journal of Competitiveness, 9(4). 81-93. DOI: 10.7441/joc.2017.04.06 
47. OLÁH, J. - KRISÁN, E. - KISS, A. - LAKNER, Z. - POPP, J. (2020): PRISMA Statement for Reporting Literature Searches in Systematic Reviews of the Bioethanol Sector. Energies, 13(9), 2323. DOI: 10.3390/en13092323

48. POPP, J.- HARANGI-RÁKOS, M. - ANTAL, G. - BALOGH, P. - LENGYEL, P. OLÁH, J. (2016): Substitution of traditional animal feed with coproducts of biofuel production: economic, land-use and GHG emissions implications. Journal of Central European Green Innovation, 4(3), 1-17.

49. POPP, J. - HARANGI-RÁKOS, M. - OLÁH, J. (2017): A megújuló energia termelésének globális kilátásai az energiafogyasztásban Magyarországon. Logisztikai Trendek és Legjobb Gyakorlatok, 3(2), 55-60.

50. RAJAGOPAL, D. - ZILBERMAN, D. (2007): Review of environmental, economic and policy aspects of biofuels. Policy research working paper, 4341. Forrás: World Bank, http://documents.worldbank.org/curated/en/393941468339901359/Review-ofenvironmental-economic-and-policy-aspects-of-biofuels. Letöltés dátuma: 2020. 12. 31.

51. RAMCILOVIC-SUOMINEN, S. - PÜLZL, H. (2018): Sustainable development - a 'selling point' of the emerging EU bioeconomy policy framework?. Journal of Cleaner Production, Volume, 172., 4170-4180. DOI: 10.1016/j.jclepro.2016.12.157

52. SEARCHINGER, T. - HEIMLICH, R. (2015). Avoiding Bioenergy Competition for Food Crops and Land. World Resources Institute. Forrás: https://agrilinks.org/sites/default/files/resource/files/WRI\%20Avoiding\%20Bioenergy\% 20Competition\%20for\%20Food\%20Crops\%20and\%20Land.pdf. Letöltés dátuma: 2020. 12. 31.

53. SEARCHINGER, T. - WAITE, R. - HANSON, C. - RANGANATHAN, J. - DUMAS, P. - MATTHEWS, E. (2019): Creating a sustainable food future: a menu of solutions to feed nearly 10 billion people by 2050. World Resources Institute:, pp. 1-556. Forrás: https://reliefweb.int/report/world/world-resources-report-creating-sustainable-foodfuture-menu-solutions-feed-nearly-10. Letöltés dátuma: 2020. 12. 31.

54. SOLOMON, B.D. (2008): Regional economic impacts of cellulosice than ol development in the North Centralstates. In: Solomon, B.D. - Luzadis, V.A.(eds.): Renewable Energy From Forest Resources in the United States. Oxford, UK: Routledge, pp- 281-298.

55. SRIVASTAVA, S.K. (2007): Green supply-chain management: a state-of-the-art literature review. International Journal of Management Reviews, 9., 53-80. DOI: 10.1111/j.1468-2370.2007.00202.x

56. SEIXAS, R. - VIART, N. - SLAVINSKI, S. (2021): Bonsucro outcome report 2018. Executive summary, pp $1-48 . \quad$ Forrás: https://www.evidensia.eco/resources/280/download/

57. UNICA (2010): EPA Reaffirms Sugarcane Biofuel is Advanced Renewable Fuel with 61\% Less Emissions than Gasoline. Institutional Network of Universities from the Capitals of Europe. Forrás: http://english.unica.com.br/releases/show.asp?rls. Letöltés dátuma: 2020. 12. 31.

58. US EPA (2019): EPA Finalizes RFS Volumes for 2019 and Biomass Based Diesel Volumes for 2020. United States Environmental Protection Agency. Forrás: https://www.federalregister.gov/documents/2017/12/12/2017-26426/renewable-fuelstandard-program-standards-for-2018-and-biomass-based-diesel-volume-for-2019 Letöltés dátuma: 2020. 12. 31.

59. VALKÓ, G. - FEKETE-FARKAS, M. - KOVÁCS, I. (2017): Indicators for the economic dimension of sustainable agriculture in the European Union. Regional Statistics, 7(1), pp. 179-196. DOI: 10.15196/RS07110 
60. VAN DAM, J. - JUNGINGER, M. - FAAIJ, A. - JÜRGENS, I. - BEST, G. FRITSCHE, U. (2008): Overview of recent developments in sustainable biomass certification. Biomass and Bioenergy, 32(8), 749-780. DOI: 10.1016/j.biombioe.2008.01.018

61. VAN GRINSVEN, A. - KAMPMAN, B. (2015): Assessing progress towards implementation of the ILUC Directive, Delft, CE Delft. Forrás: https://theicct.org/sites/default/files/publications/CE_Delft_4H38_Assessing_progress_t owards_implementation_ILUC_dir.pdf. Letöltés dátuma: 2020.12.31.

\section{Szerzők}

\section{Prof. Dr. OLÁH Judit}

DSc, egyetemi tanár

Debreceni Egyetem, Gazdaságtudományi Kar Alkalmazott Informatika és Logisztika Intézet H-4032 Debrecen, Böszörményi út 138.

olah.judit@econ.uideb.hu

\section{Dr. ERDEI Edina}

posztdoktor

Debreceni Egyetem, Gazdaságtudományi Kar

Alkalmazott Informatika és Logisztika Intézet H-4032 Debrecen, Böszörményi út 138.

erdei.edina@econ.unideb.hu

\section{Prof. Dr. POPP József}

egyetemi tanár

MTA levelező tagja

Neumann János Egyetem

MNB-Tudásközpont

6000 Kecskemét, Izsáki út 10.

popp.jozsef@uni-mate.hu 